\title{
INFLUENCE OF PRINCIPALLEADERSHIP AND TEACHER TEACHING PERFORMANCE ON LEARNING ACHIEVEMENT OF STUDENTS CLASS VIII OF AL-KHAIRIYAH MIDDLE SCHOOL (SMP) SURABAYA
}

\author{
Rusman \\ Email: rusman@gmail.com
}

\begin{abstract}
This study is to determine the effect of principal leadership, teacher teaching performance on student achievement. The method used in this study was quantitative statistics. To get good and correct data, researcher used structured questionnaires and documentation. After the data was collected, it was analyzed using the product moment correlation formula, then continued by using multiple correlation formula, after that, it was proceeded bythe percent formula. To make easier to calculate and conclude, the researcher complements the pedestrian table, helper table and formulas of $\mathrm{F}_{\text {calculation }}$ and $\mathrm{F}$ table. The findings of this study can be concluded: first, the principal leadership and the teacher performance could be said to have an influence / positive with a statistical value of 30.08, Second, from the result of statistical analysis using Two Paths with manual calculation it can be calculated as 12.22 and a significance of 5,93, $100 \%=56.25 \%$. This means that the contribution of teacher performance on the learning achievement of the eighth grade students of junior high school (SMP) Al-Khairiyah Surabaya that if it is presented in percentage reaching $56.25 \%$.
\end{abstract}

Keywords: Leadership, Performance, Achievement

\section{A. INTRODUCTION}

In the 1945 constitution which contains about the national objectives of the Indonesian nation, where they formulated and charted to educate the nation's children through the education unit, Indonesian Constitution number 20 of 2013 in chapter 1 and part 1 which states that the education system is every effort that is done consciously and planned to realize active students and able to develop the potential that exists in their 
respective talents. ${ }^{1}$ Therefore, a person must be able to provide lessons that are very good and also brilliant even though a teacher must know the potential of his students first, and also the teacher must be smart in analyzing his students' talents so that the generation of this nation is more radiant.

To achieve all, a unit / place is needed as a place for the teaching and learning activities take place, and what really determines all of these is the presence of an intelligent principal and very effective teacher performance, indeed many factors for the success of a school but the most decisive is the genius principal's leadership and the discipline of teacher teaching performance. ${ }^{2}$

According to Mulyasa, a school principal must carry out his role as leader by carrying out the functions: principal is as an educator. The principal who shows high commitment and focuses on curriculum development and teaching and learning activities in his school will of course pay great attention to the level of competence the teachers has, at the same time, he will always try to facilitate and encourage the teachers to continuously improve their competence, so that teaching and learning activities can run effectively and efficiently.

Principal is as a manager. In this case, the principal should be able to facilitate and provide wide opportunities for teachers to be able to carry out professional development activities through various education and training activities, both carried out in schools such as Subject Teacher Discussion Forum (MGMP), professional discussions and so on or through education and training activities out of school, such as the opportunity to continue their education or take part in various training activities organized by other parties.

Principal is as administer. It is especially related to financial management, that the achievement of teacher competency cannot be separated from the cost factor. How big a school can allocate a budget to increase teacher competency will certainly affect the level of competence of its teachers. Therefore the principal should be able to allocate an adequate budget for efforts to improve teacher competence.

\footnotetext{
${ }^{1}$ MPRRI, Basic Law of the Republic of Indonesia Year 1945 and Decree of the People's Consultative Assembly of the Republic of Indonesia (Jakarta: tp 2017), 191.

${ }^{2}$ Ibid., 192.
} 
Principal is as a supervisor who can find out how far the teacher is able to carry out learning, periodically the principal needs to carry out supervision activities, which can be done through class visits to observe the learning process directly, especially in the selection and use of methods, the media used and the student involvement in learning process.

Principal is as a leader. What the principal leadership style can foster creativity while at the same time it can encourage the teacher competency improvement? In the leadership theory we know at least two leadership styles; namely task-oriented leadership and human-oriented leadership. In order to improve the teacher competency, a principal can apply both leadership styles appropriately and flexibly, adapted to existing conditions and needs. A person's leadership is closely related to the personality and personality of the principal as a leader will be reflected in the traits of honesty, confidence, responsibility, courage to take risks and decisions, being big soul, stability and exemplary emotions.

Principal is as a creator of work climate, and culture. A conducive work climate will enable each teacher to be more motivated to show superior performance, accompanied by efforts to improve each competence. Principal is as an entrepreneur. In applying entrepreneurial principles associated with improving teacher competence, the principal should be able to create renewal, comparative advantage, and take advantage of various opportunities. The principal with a strong attitude of courage will dare to make innovative changes in the school, including changes in matters relating to the student learning process and the competence of the teachers. ${ }^{3}$

Wahjosumidjo interprets the leaders of the education unit who interact directly in the education unit as functional personnel, the teachers are given mandate to help to run the school / participate in controlling how the school runs, including learning activity, skills and the others related to education or in a place where there is a transfer of knowledge or matters of knowledge that can bring change to the person given the knowledge (students). What is intended by the word "lead" means the skill possessed by someone to move / run the school wheel so that the goal of the school can be achieved in accordance with agreement upon beforehand.

\footnotetext{
${ }^{3}$ Mulyasa, Becoming a Professional School Principal (Bandung: PT. Remaja, 2009), 98.
} 
The teacher is one of the factors that are no less important than the principal who is able to move or make school trips better and develop as productive as possible. Then for school leaders (principals) must be able to provide positive stimulus and motivation to the educators so that they are more passionate in carrying out their duties in the school. It can be in the form of reward for success in carrying out their duties, there is no separation between the principal and the teacher so that if there are things that are not desired, the teachers do not feel embarrassed to express / often together without having to wait for a formal meeting to resolve the problem or brilliant ideas.

The teacher's most important mandate is to transmit or transfer knowledge to the students to be made a provision by them so that they can continue to the next level. The action to do what is entrusted to the teacher is called performance. Therefore, the performance of the teacher can we understand that it is the most decisive achievement of an educational goal, or the student achievement depends on the performance of the educator or teacher.

Fattan said that the definition of performance is an expression of skill based on knowledge, attitude and motivation in producing something to achieve goals. Sedermayanti said that the definition or interpretation of the performance is an interpretation of the 4 performances; (1). Work achievement, (2). Work implementation, (3). Work target, and (4). Job performance or work performance. Achievement is the result of a job or task that is done, while academic achievement is learning outcomes done in school or on campus in learning activities that are more positive and usually determined by value. ${ }^{4}$

Learning achievement is defined as the mastery of knowledge or skills that are developed in the subjects, usually indicated by the value or number given by the teacher or in other words learning achievement is student learning outcomes achieved when students follow and do assignments or learning activities and those that are valued in terms of the cognition or knowledge of the students whose ending the teacher gives value with numbers. ${ }^{5}$

According to Sumadi Suryabrata, achievements can also be defined as follows: value is the final formulation that can be given by the teacher regarding the progress /

\footnotetext{
${ }^{4}$ Mulyasa, BeingTeacher, 36.

${ }^{5}$ Sincerity, Role of Discipline on Student Behavior and Achievement (Jakarta: PT. Grasindo, 2017), 75.
} 
achievement of student learning during a certain period ". So, achievement is the result of students' activities during a certain period of activities. In Hutabarat's opinion, learning outcomes are divided into four groups; (1) Knowledge, namely in the form of information material, facts, ideas, beliefs, procedures, laws, rules, standards and other concepts. (2) Ability, namely in the form of the ability to analyze, reproduce, create, organize, summarize, generalize, think rationally and adjust, (3) Habits and skills, namely in the form of behavioral habits and skills in using all abilities, and (4) Learning achievement is a necessary students to find out the abilities gained from an activity called learning.

From the explanation above, the researcher was interested in choosing the research subject, namely Junior High School (SMP) Al-Khairiyah, Islamic School located in the area of north Surabaya, precisely on Jalan Iskandar Muda No. 36 Surabaya. Al-Khairiyah high school is a fairly educational unit that has been established for a long time but is still able to survive and keep putting out students who are qualified or able to compete with the students from the other schools that have popular names in Indonesia such as Al-Irsyad, Barunawati and Ta'miriyah, which these schools are national-level schools whose location are not far from Al-Khairiyah high school in North Surabaya. From the relatively high level of backgroud according to the researcher, it is very interesting, so the author feels interested in researching and studying it. . The research formulation is (1) How is the Effect of Principal Leadership and Teaching Performance on teachers in Al-Khairiyah Junior High School (SMP) Surabaya ?; (2) How influence does the headmaster's leadership and teacher's teaching performance have on student achievement in the Al-Khairiyah (SMP) junior high school in Surabaya ?; While the objectives of this study are: (1) To find out the influence of the principal's leadership and teacher's teaching performance at Al-Khairiyah Junior High School (SMP) Surabaya; (2) To find out how influence the principal's leadership and teacher's teaching performance have on student achievement in Al-Khairiyah junior high school (SMP) Surabaya.

\section{B. RESEARCH METHODS}

This study used a quantitative statistical research method that takes place using a closed structured questionnaire approach and documentation as a data collection 
instrument. Imam Bawani said that a researcher must first determine the type of research before the researcher conducts the research because each research method will produce different consequences. The researcher used the type of method, namely multiple correlation which means showing the direction or strength of the relationship between one variable and another variable ( 2 independent variables with 1 dependent variable). In this study the researcher made the influence of the principal's leadership is an independent variable or X1, the teacher performance of teaching or is called X2 and the student achievement is the dependent variable symbolized by the letter Y.

For easier calculation of multiple correlations, the researcher firstly calculated simple correlation through product moment of Pearson correlation first. For the calculation of the Dual Correlation, which through simple correlations was done with the following formula and completed with the first clearer help table; (1) Making $\mathrm{H}_{\mathrm{a}}$ and $\mathrm{H}_{\mathrm{o}}$ in sentence form; (2) Making $\mathrm{H}_{\mathrm{a}}$ and $\mathrm{H}_{\mathrm{o}}$ in statistical form; (3) Creating a helper table to calculate multiple correlation values; (4) Entering statistic values from the auxiliary table into the formula; (5) Testing the significance with the formula $\mathrm{F}$ counting; (6) Making the guidelines table of strong and the low correlation; (7) Making conclusions.

\section{B. RESEARCH RESULTS AND DISCUSSION}

Data presented of this study were obtained from instruments in the form of structured questionnaires and also documentation of student learning achievement taken from report cards for grade VIII students of semester I-II in academic year 2017-2018. The independent variable of this study was principal leadership (which is given the symbol $\mathrm{X}_{1}$ ) and the second independent variable was the teacher's teaching performance (which is given the symbol $\mathrm{X}_{2}$, where the two variables that were looked for in relation to the dependent variable.

The dependent variable was learning achievement of the eighth grade students of the (SMP) Al-Khairiyah middle school, Surabaya (symbol Y). To answer from the first formulation of the problem, how is the influence of the principal's leadership and teacher's teaching performance on student learning achievement? The first step to do is making $\mathrm{H}_{\mathrm{A}}$ and $\mathrm{H}_{\mathrm{O}}$ in the form of sentences, $\mathrm{H}_{\mathrm{O}}$ : There is no relationship between the principal's leadership and teacher's teaching performance on student achievement, $\mathrm{H}_{\mathrm{A}}$ : 
There is a relationship between the principal's leadership and teacher's teaching performance on student achievement $\mathrm{H}_{\mathrm{A}}$ and $\mathrm{H}_{\mathrm{O}}$ in symbolic form: $\mathrm{H}_{\mathrm{O}}: \rho=0 ; \mathrm{H}_{\mathrm{A}}: \rho \neq 0$. Then, the next step is making a helpful table.

Helper Table

\begin{tabular}{|c|c|c|c|}
\hline No & $\mathrm{X}_{1}$ & $\mathrm{X}_{2}$ & $\mathrm{Y}$ \\
\hline & 732 & 714 & 1847 \\
\hline
\end{tabular}

Table of guidelines of low and strength of relationship

\begin{tabular}{|c|c|}
\hline Co-efficient interval & Relational Level \\
\hline $0,00-0,199$ & Very Low \\
\hline $0,20-0,399$ & Low \\
\hline $0,40-0,599$ & Medium \\
\hline $0,60-0,799$ & High \\
\hline $0,80-1,000$ & Very High \\
\hline
\end{tabular}

This table is / as a guide / reference to whether a correlation is strong or not about the principal leadership and teacher performance on student learning achievement, if the coefficient interval ranges from 0,00 to 0,199 then the relationship between the principal's leadership and teacher's performance on student achievement is very weak, if the coefficient interval ranges from 0,20 to 0,399 , the relationship between the leadership of the principal and the teacher's performance on student achievement is stated to be low. If the interval ranges from 0,40 to 0,599 then the relationship between the principal's leadership and teacher performance towards student achievement is stated to be medium, if the coefficient interval ranges from 0,60 to 0,799 , the relationship between the principal's leadership and teacher's performance on student achievement is stated high. If the coefficient interval ranges from 0,80 to 1,000 then the relationship between the principal's leadership and teacher performance on student achievement is stated high. After making a strong and low relationship guide, then, the next step is summarizing the statistics. 
Statistical Summary: $\mathrm{X}_{1}$ with $\mathrm{Y}$

\begin{tabular}{|c|c|}
\hline Symbol statistics & Value Statistics \\
\hline $\mathbf{N}$ & 22 \\
\hline $\boldsymbol{\Sigma} \mathbf{X}_{\mathbf{1}}$ & 732 \\
\hline $\boldsymbol{\Sigma} \mathbf{y}$ & 1847 \\
\hline $\boldsymbol{\Sigma} \mathbf{X}_{\mathbf{1}}{ }^{2}$ & 535824 \\
\hline $\boldsymbol{\Sigma} \mathbf{y}^{\mathbf{2}}$ & 3411409 \\
\hline $\boldsymbol{\Sigma} \mathbf{X}_{\mathbf{1}}$ & 1366780 \\
\hline
\end{tabular}

This statistical summary is used to make easier for the researcher to calculate to be included in a simple formula of correlation product moment or multiple correlations. We firstly look for relationships / influences between the leadership of the school principals on the student learning achievement by using a simple formula of product moment as follows:

$$
\begin{aligned}
& N\left(\sum X_{1} Y\right)-\left(\sum X_{1}\right) \cdot\left(\sum Y\right) \\
& \mathrm{r} \mathrm{X}_{1} \mathrm{Y}= \\
& \sqrt{ }\left(\text { n. } \sum X_{1}{ }^{2}-\left(\sum X_{1}\right)^{2}\right) \cdot\left(\text { n. } \sum y^{2-}\left(\sum Y\right)^{2}\right. \\
& 22(732.1847)-(732) .(1847) \\
& \mathrm{r} \mathrm{X}_{1} \mathrm{Y}= \\
& \sqrt{ } \quad 22 .\left(535824-(535824) .\left(22.3411409^{-}(3411409)\right.\right. \\
& (29744088)-(1366780) \\
& r X_{1} Y=\overline{\sqrt{(11252304) .(71639589)}} \\
& 28377308 \\
& \text { r } X_{1} \mathrm{Y}= \\
& \sqrt{ } \quad 806110433863056 \\
& 10975608 \\
& \mathrm{r} \mathrm{X}_{1} \mathrm{X}_{2}= \\
& 11233892,93=0,99
\end{aligned}
$$


The results of the calculation above can be concluded that the relationship between the leadership of the principal to the learning of eighth grade students of AlKhairiyah junior high school (SMP) Surabaya is positive or strong, to find out the contribution of variable $\mathrm{X}_{1}$ on variable $\mathrm{Y}$, we determine the formula $\mathrm{R}^{2} \times 100 \%$ or $0.99^{2}$ $\mathrm{x} 100 \%=96.04 \%$, which means the contribution of the principal's leadership to the learning achievement of the eighth grade students of Al-Khairiyah junior high school (SMP) Surabaya if it is presented in percentage reaching 96.04\%. After testing with the statistical formula then it was proceeded with testing with the formula $F_{\text {count }}$ and $F_{\text {table. }}$
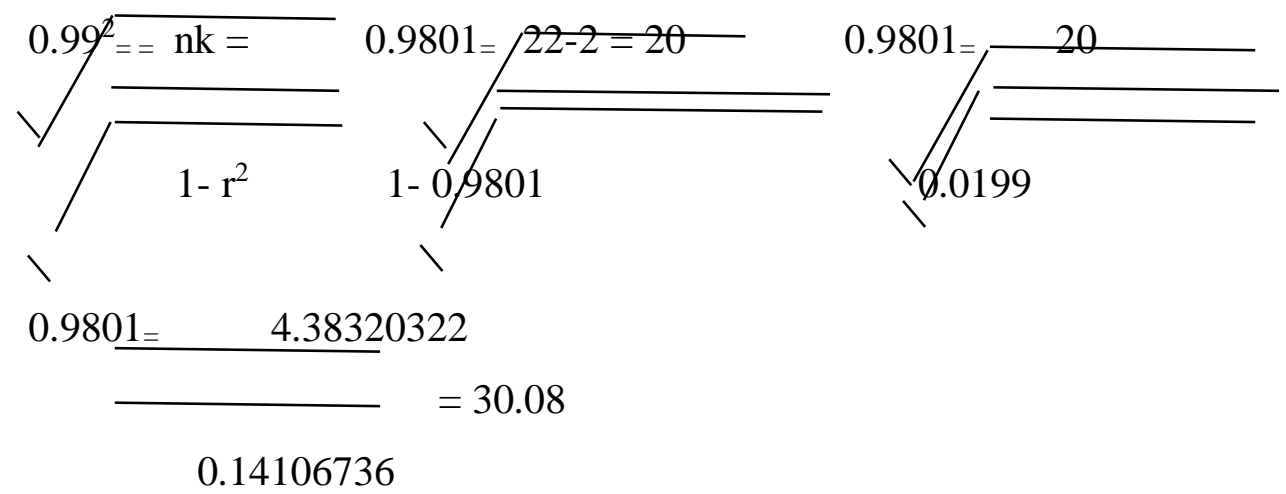

From the above calculation, it can be assumed that there is a relationship between the teaching performance of the teacher and the learning achievement of the eighth grade students of Al-Khairiyah junior high school (SMP) Surabaya which is positive or strong. To know the contribution of the independent variable $X_{2}$ on the dependent variable $\mathrm{Y}$ then the researcher used the following formula:

$$
\mathrm{R}^{2} \times 100 \% \text { or } 0.88^{2} \times 100 \%=77.44 \%
$$

Based on the formula, the researcher suggests that the teaching performance contribution of the teacher on the learning achievement of grade VIII students AlKhairiyah junior high school (SMP) Surabaya if it is stated using the formula is 77.44\%. After knowing the contribution, to understand the better validity of the correlation $\mathrm{X}_{2}$ and $\mathrm{Y}$, the researcher tested it using the formula $\mathrm{F}$ counting and $\mathrm{F}$ table as follows:

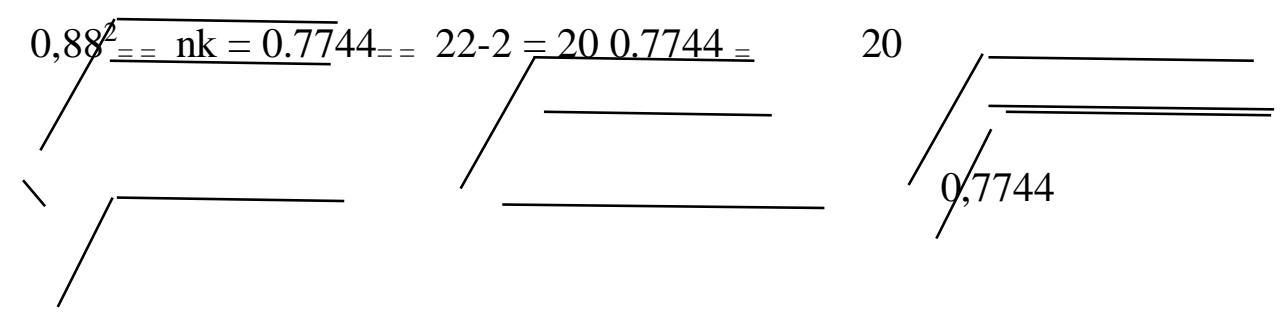




$$
1-r^{2} \quad \backslash \quad 1-0,7744
$$

\section{3,463222083551674}

$0.4749736834815167=7.30$

Based on the calculation provided the error rate, $\alpha=0.05, \mathrm{db}=\mathrm{n}-2=22-2=20$ so that $\mathrm{F}_{\text {table }}=5.58$, therefore, it can be drawn that $\mathrm{T}_{\text {counting }} \geq \mathrm{T}_{\text {table }}$ or $7.30,55.58$ or in other words $\mathrm{H}_{\mathrm{A}}$ is accepted and $\mathrm{H}_{\mathrm{O}}$ is rejected / $\mathrm{HA}: \rho \neq 0$ and $\mathrm{HO}: \rho=0$

Then, it can be concluded that the correlation of variable $\mathrm{X}_{2}$ and variable $\mathrm{Y}$ or in other words the influence of the principal's leadership on student achievement in class VIII Al-Khairiyah junior high school (SMP) Surabaya is positive or strong.

1. Statistics summary: $\mathrm{X}_{1}$ and $\mathrm{X}_{2}$

\begin{tabular}{|c|c|}
\hline STATISTICAL SYMBOL & VALUE \\
\hline $\mathbf{N}$ & 22 \\
\hline $\boldsymbol{\Sigma} \mathbf{X}_{\mathbf{1}}$ & 732 \\
\hline $\boldsymbol{\Sigma} \mathbf{X}_{\mathbf{2}}$ & 714 \\
\hline $\boldsymbol{\Sigma} \mathbf{X}_{\mathbf{1}}{ }^{2}$ & 535824 \\
\hline $\boldsymbol{\Sigma} \mathbf{X}_{\mathbf{2}}{ }^{2}$ & 509796 \\
\hline $\boldsymbol{\Sigma} \mathbf{X}_{\mathbf{1}} \mathbf{X}_{\mathbf{2}}$ & 522648 \\
\hline
\end{tabular}

Based on the calculation provided the error rate, $\alpha=0.05 ; \mathrm{db}=\mathrm{n}-2=22-2=$ 20 so that in $\mathrm{F}_{\text {table }}=5.58$, it can be concluded that $\mathrm{T}_{\text {count }} \geq \mathrm{T}_{\text {tableor }} 30.08 \geq 5.58$ or in other words $\mathrm{H}_{\mathrm{A}}$ is accepted and $\mathrm{H}_{\mathrm{O}}$ is rejected / HA: $\rho \neq 0$ and HO: $\rho=0$.

From the explanation above, the researcher concluded that the correlation of the independent variable $\mathrm{X}_{1}$ and the dependent variable $\mathrm{Y}$ or in other words, the influence of the principal's leadership on the learning achievement of the eighth grade students of Al-Khairiyah Junior High School (SMP) Surabaya is positive or strong.

After finding the relationship between the principal's leadership and the student's learning achievement with a simple formula, then the relationship / influence of the teacher's performance on the student's learning achievement with the same step, 
it is followed by finding a relationship between the principal's leadership on the student achievement.

Statistical Summary: $\mathrm{X}_{2}$ and $\mathrm{Y}$

\begin{tabular}{|c|c|}
\hline Statistical Symbol & Statistical Value \\
\hline $\mathbf{N}$ & 22 \\
\hline $\boldsymbol{\Sigma} \mathbf{X}_{\mathbf{2}}$ & 2714 \\
\hline $\boldsymbol{\Sigma} \mathbf{y}$ & 1847 \\
\hline $\boldsymbol{\Sigma} \mathbf{X}_{\mathbf{2}}^{2}$ & 509796 \\
\hline $\boldsymbol{\Sigma} \mathbf{y}^{2}$ & 3411409 \\
\hline $\boldsymbol{\Sigma} \mathbf{X}_{2} \mathbf{y}$ & $1,318,758$ \\
\hline
\end{tabular}

This statistic summary is to facilitate the researcher in counting to be put into an simple formula correlation product moment or multiple correlations. We firstly look for relationships / influences between performance teaching on the student achievement by using a simple formula of product moment as follows:

$$
\begin{aligned}
& \mathrm{n}\left(\sum \mathrm{X}_{2} \mathrm{Y}\right)-\left(\sum \mathrm{X}_{2}\right) \cdot(\mathbb{Y} \mathrm{Y}) \\
& \mathrm{r} \mathrm{X}_{2} \mathrm{Y}= \\
& \sqrt{ }\left(\text { n. } \sum \mathrm{X}_{2}^{2}-\left(\sum \mathrm{X}_{2}\right)^{2}\right) \cdot\left(\text { n. } \sum \mathrm{y}^{2-}\left(\sum \mathrm{Y}\right)^{2}\right) \\
& 22(714.1847)-(714) .(1847) \\
& \mathrm{r} \mathrm{X}_{2} \mathrm{Y}= \\
& \sqrt{ } \text { (22. 509796-(509796).(22. 3411409-(3411409) } \\
& \text { 22(1318758)-(1318758) } \\
& \mathrm{r} \mathrm{X}_{2} \mathrm{Y}=\overline{\sqrt{(11215512-509796) .(75050998-3411409)}} \\
& \text { 29012676-1318758) } \\
& \mathrm{r} \mathrm{X}_{2} \mathrm{Y}= \\
& \sqrt{ } 10705716.71639589 \\
& 27693918 \\
& \mathrm{r} \mathrm{X}_{2} \mathrm{Y}=
\end{aligned}
$$




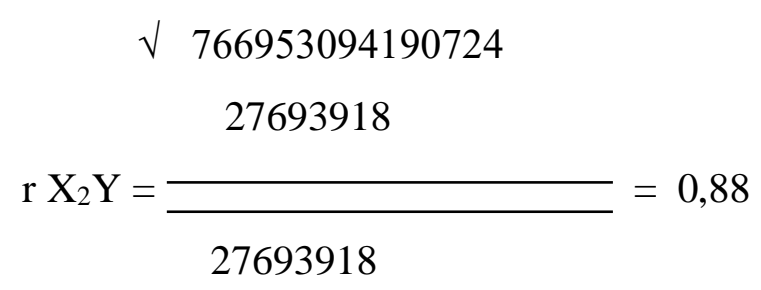

After calculating, it can be concluded that the relationship of the principal's leadership to the learning of eighth grade students of Al-Khairiyah junior high school (SMP) Surabaya is positive or strong. To find out the contribution of variable $\mathrm{X}_{1}$ on the variable $\mathrm{X}_{2}$, we determine the formula $\mathrm{R}^{2} \times 100 \%$ or $0.99^{2} \times 100 \%=96.04 \%$. or in other words $\mathrm{H}_{\mathrm{A}}$ is accepted and $\mathrm{HO}_{\mathrm{O}}$ is rejected / $\mathrm{HA}: \rho \neq 0$ and HO: $\rho=0$, then, it is tested with $\mathrm{F}_{\text {counting }}$ and $\mathrm{F}_{\text {table. }}$

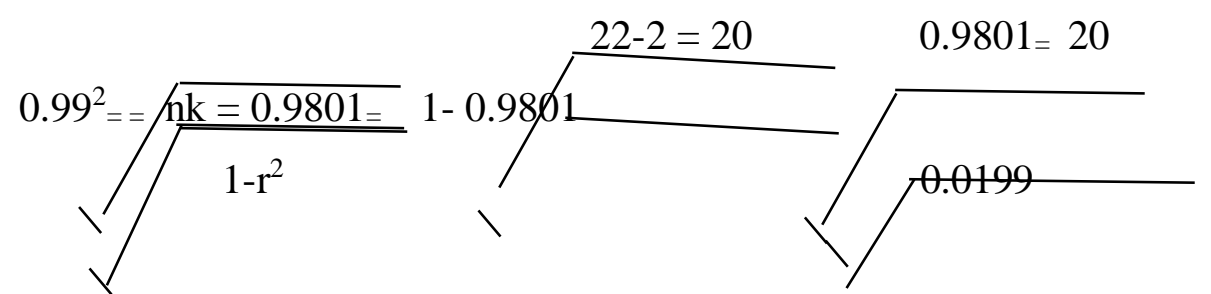

4,38320322

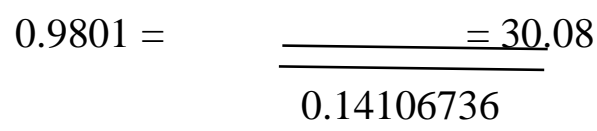

Based on calculations with the provisions of the error rate, $\alpha=0.05, \mathrm{db}=\mathrm{n}-2=$ $22-2=20$ so that $F_{\text {table }}=5.58$, so that the conclusion can be drawn that $\mathrm{T}_{\text {count }} \geq \mathrm{T}_{\text {table }}$ or $30.08 \geq 5.58$.

With the conclusion that the correlation of variables $\mathrm{X}_{2}$ with variable $\mathrm{Y}$ or in other words the influence of the principal's leadership on the learning achievement of the eighth grade students of Al-Khairiyah Junior High School (SMP) Surabaya is positive or strong.

The next step is to find relationship of the principal leadership and the teacher's performance on student achievement with the multiple correlation formula.

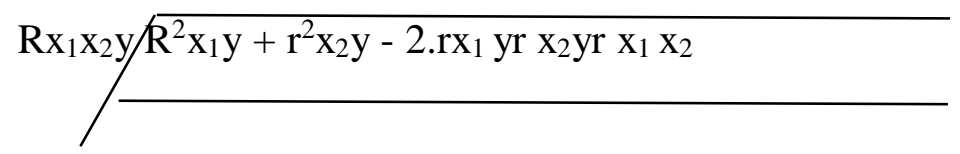



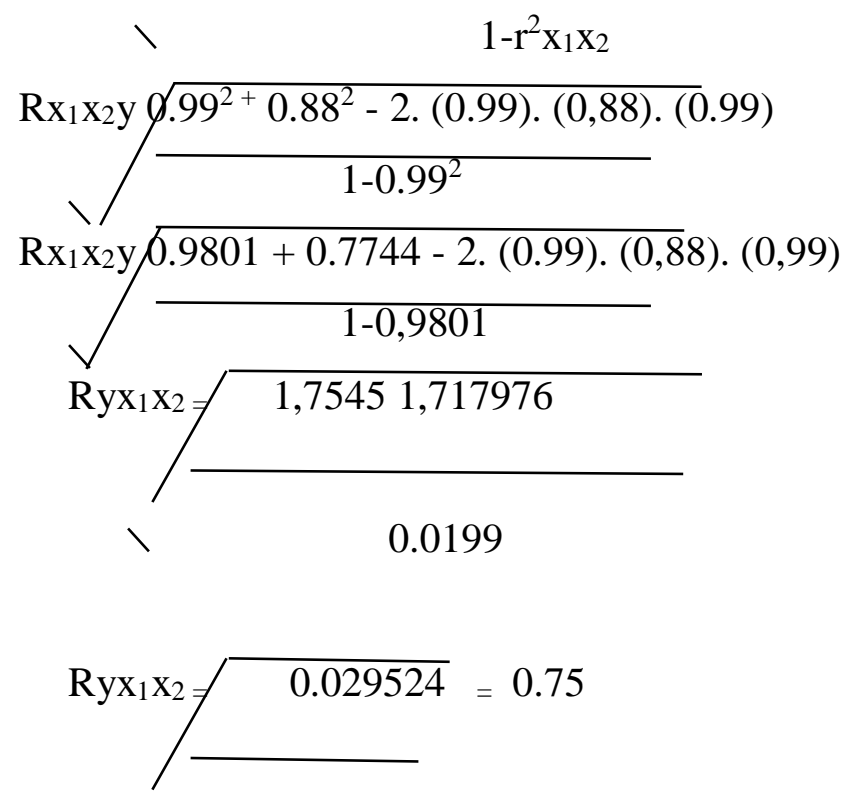

0.0396eighth

Relationship between the principal's leadership and the teaching performance of teachers on learning of eight grade students of Al-Khairiyah junior high school (SMP) Surabaya is positive or strong. To find out the contribution of variables $\mathrm{X}_{1}$ and $\mathrm{X}_{2}$ and variable $\mathrm{Y}$, the researcher determines the formula $\mathrm{R}^{2} \times 100 \%$ or $0.75^{2} \times 100 \%$ $=56.25 \%$. This means that contribution of the principal leadership ad the teacher teaching performance on the learning achievement of the eighth grade students of AlKhairiyah junior high school (SMP) Surabaya if it is presented with a percentage reaching 56.25 .

The formula $\mathrm{F}_{\text {count }}$ and $\mathrm{F}_{\text {table }}$ (Double Correlation)

$$
\mathrm{F}_{\mathrm{h}}=\mathrm{R}^{2} / \mathrm{K}
$$

( $1-\mathrm{R}^{2} /(\mathrm{nk}-1)$, Methods of Test $\mathrm{F}_{\text {counting }}$

$\mathrm{F}_{\text {counting }} \geq \mathrm{F}_{\text {table }}$ then significant / any influence. $\mathrm{F}_{\text {counting }} \leq \mathrm{F}_{\text {table }}$ then insignificant / no effect, formula $F_{\text {table; }} \alpha=0.01$ or $\alpha=0.05 . F_{\text {table }}=F(1-\alpha)(d b=K) .(D b=n k-1)$ $\mathrm{F}_{\mathrm{h}}=0.75^{2 / 2} \mathrm{~F}_{\mathrm{h}}=0.28125$ $\mathrm{Fh}=$ 0.28125 $\overline{(1-0.28125 /(22-2-1)}$ 
After calculating, the results of the test $F_{\text {arithmetic }}$ and $F_{\text {table }}$ can be concluded that $F_{\text {counts }} \geq F_{\text {table }}$ or $12,22 \geq 5,93$. So it means that there is a positive or strong relationship between the principal's leadership and teacher's teaching performance on the teaching achievement of the Al-Khairiyah Junior High School (SMP) students of grade VIII in semester 1-2. From the results of the above explanation by calculating with the formula of the product moment statistics, multiple correlations and also with the formula $F_{\text {counting }}-F_{\text {table, }}$, the researcher can conclude that the principal leadership and teacher teaching performance affect the student learning achievement by $56.25 \%$.

\section{CONCLUSIONS AND SUGGESTION}

From the above explanation the researcher can conclude as follows:

1. From the results of statistical analysis using Anova one track with manual calculation, to test the first hypothesis found the price of $F_{\text {counting }}$ is 30.08 , while $F_{\text {table }}$ is 5.58, then $\mathrm{H}_{\mathrm{A}}$ is accepted and $\mathrm{H}_{\mathrm{O}}$ is rejected, in the other word, the principals' leadership is stated positive or strong.

2. From the results of statistical analysis using Two Paths with manual calculation can be obtained $\mathrm{F}_{\text {counting }}$ of 12.22 and a significance of 5.93 then $\mathrm{H}_{\mathrm{A}}$ is accepted and $\mathrm{H}_{\mathrm{O}}$ is rejected, if $5.93100 \%$ is added $=56.25 \%$. So it is concluded that the leadership contribution of the principal and the teaching performance of the teacher is $56.25 \%$, in other words the principal leadership and the teacher teaching performance have a profound effect on student achievement.

In order to improve the quality of the principal leadership and also in spurring and fostering the quality of the teacher performance at Al-Khairiyah high school Surabaya, the researcher provide the following suggestions:

1. The results of this study are positive and strong, the principal leadership has a positive value on the student learning achievement, then for the leaders (principals) in particular, they have to always maintain the quality of their performance by always learning and learning and also evaluating the results rather than their own performance.

2. The results of this study are positive and also strong, teacher's teaching performance has a positive influence on the student learning achievement so for the teachers in 
particular they always maintain the quality of their performance by always learning and learning and also evaluating the results rather than their own performance.

\section{E. REFERENCES}

Bahri, Syaiful. 2010. Teaching and Learning Strategies. Jakarta: RenekaCipta.

Bawani, Imam. 2016. Islamic Education Research Methodology. Sidoarjo: KhasanahIlmuSidoarjo.Damsar, 2011. Educational Sociology. Jakarta: KencanaPrenada Group.

Kartini, Kartono. 2016. Leaders and Leadership. Jakarta: Raja GrafindoPersada.

Muhaimain. 2018. Development of PAI Curriculum. Jakarta: Raja GrafindoPersada.

Nata, Abuddin 2013. History of Islamic Education. Jakarta: PT. Raja GrafindaPersada.

Nazir. 1988. Research method. Jakarta: Ghalia Indonesia.

Oemar. 2013. Teaching and Learning Process. Jakarta: BumiAksara.

Ridwan. 2013. Statistics Basics. Bandung: Alfabeta.

Rohiat. 2010. School management. Bandung: PT RefikaAditama.

Sobirin.2018.Principal, Teacher and learning. Bandung: Nuance publisher.

Sugiono. 2015. Statistics for Research. Bandung: Alfabeta

Sugiono. 2015. Statistics for Research. Bandung: Alfabeta.

Sugiyono. 2009. Research Methods Quantitative Approach. Bandung: Alfabeta

Suharsismi.2010.Research Procedure Practice Approach. Jakarta: RenekaCipta.

Sukardi. 2008. Education \& Operational Evaluation. Jakarta: BumiAksara

Supranto. 2016. Statistical Theory and Application. Jakarta: Erlangga.

WinaSanjaya. 2014. Education-oriented Standards for Educational Process Standards. Jakarta: KencanaPrenanada Media group.

Sincere. 2017. The disciplinary role in student behavior and achievement. Jakarta: PT. Grafindo.

Sugiyono. 2009. Research Methods Quantitative, Qualitative and $R \& D$ Approaches. Bandung: Alfabeta. 